\title{
Signaling of IL 4 and IL 13 Genetic Variants in Asthma Pathogenesis
}

\author{
Pratibha Dixit $^{1}$, Shally Awasthi ${ }^{2}$ \\ King Georgees Medical University, Lucknow, U.P., India
}

\begin{abstract}
Prevalence of chronic disorder like asthma has dramatically increased in recent decades. These are mainly disorder of immune system, the results of complex interactions among various genetic and environmental factors. Interleukin 4 and 13, a Th2- type cytokine play key role in inflammatory pathway, emerged in the pathogenesis of bronchial asthma. Both are act as central regulator in IgE synthesis, mucus hyper-secretion and airway hyper-responsiveness. In this review, we described the signal transduction mechanism of IL4/13 pathway, ligand and their receptor involvement in inflammatory pathway. Summarizes the information related to the association of interleukin genes with asthma. Report ranges from studies showing positive or protective association to those showing no association. Therefore, studies with sufficiently large sample size and detailed phenotype are required to define the potential contribution of interleukin genes in the pathogenesis of asthma.
\end{abstract}

Keywords: asthma, Interleukins, polymorphisms

\section{Introduction}

Asthma is chronic obstructive pulmonary disease characterized by inflammatory reactions along with elevated IgE levels. IgE responses are mainly regulated by human major histo-compatibility complex (MHC) HLA class II and $\mathrm{T}$-cell receptor (TCR) genes and involvement of $\mathrm{T}-\mathrm{B}$ cognate interactions where as involvement of non-cognate interactions of mast cells, basophils and T cells with B cells in non-antigen-specific IgE responses ${ }^{1}$.

Interleukins (IL) 4 and 13 are highly expressed in lungs and their levels are high in peripheral blood in bronchial asthma patients ${ }^{2,3}$. Also they share common receptors and promote STAT6 (signal transducer and activator of transcription) activation (Fig. 1). Moreover their over-expression induces a bronchial asthma-like phenotype and blockage impairs the induction of a bronchial asthma-like phenotype in mice ${ }^{4,5,6}$ Till date, strong linkages have been identified to flanking markers of the human cytokine gene cluster on $5 \mathrm{q} 31^{7,8,9}$ and $16 \mathrm{p} 12^{10}$, which include ILA/IL13 and ILAR, respectively. Many groups have tried to identify variants of these genes and to test whether these are associated with asthma or atopy.

The aim of this review is therefore to summarize variants within the IL-4/IL-13 pathway and to discuss the functional aspects of these variants in relation to atopy and asthma.

\section{IL-4 and IL-13}

IL4 and IL13 are located on chromosome $5 \mathrm{q} 31$ within $25 \mathrm{~kb}$ and genome searches identified them as strong linkage with asthma and atopy ${ }^{8}$. In Caucasian populations a di-nucleotide repeat in the third intron of ILA is linked to total serum IgE levels ${ }^{7}$ but not to asthma, whereas in Japanese population linkage to both high IgE levels and asthma has been found ${ }^{11}$.

Till date, in IL4 promoter region five putative variants have been reported, of which four are very rare ${ }^{12,13}$. In American

${ }^{14}$ and Japanese populations ${ }^{11}$, C590T of IL 4 promoter has been reported to elevate $\mathrm{IgE}$ levels. It supports the candidacy of IL4 as an atopy locus on $5 \mathrm{q} 31$. In vitro it also associated with IL-4 activity and shows higher binding affinity to nuclear transcription factors ${ }^{14}$. Though, no direct link to cellular IgE synthesis has been shown and the majority of the studies cannot replicate the original association.

IL-4 and IL-13 exert similar biological activity $^{1}$; IL-13 shows unique activities. IL-13 induces patho-physiological features of asthma independent of IL-4, but dependent on IL-4Ra ${ }^{4,5}$. None of them show redundancy. These findings emphasize that IL-13 might play a key role in induction of asthma through the IL-4Ra chain. In relation to asthma ${ }^{15}$, two variants of IL13 have been identified: one is in the promoter in association with IL-13 production; and the other represents charge change, and may alter ligand-receptor binding and hence up-regulate IL-13 signaling. Test of their association of these two variants with atopy or asthma among different ethnic groups are in progress ${ }^{16}$.

\section{Receptors: IL-4R and IL-13R}

The human IL-4R is a hetero-dimeric complex comprising the IL-4Ra chain and gc chain (Fig. 1). It is also an essential component of IL-13R ${ }^{1}$. IL-4Ra-null mice lack IgE synthesis and Th2 immune reactions, suggesting that the IL-4Ra chain is a crucial component for binding and signal transduction of both IL-4 and IL-13. IL-4R located on chromosome $16 \mathrm{p}^{10}$, strong genetic linkage has been found between atopy and flanking markers whereas negative or indeterminate linkage searches have been found for this region ${ }^{7,8}$. Arg551Gln, variant of IL-4Ra has been identified in a study of individuals with hyper-IgE syndrome and severe eczema, it was found in excess ${ }^{17}$. Impaired binding of the negative regulator protein tyrosine phosphates SHP1 and increased expression of CD23 (FceRII) on peripheral blood mononuclear cells of individuals bearing the Arg551 allele after challenge with IL-4 was showed by functional analysis. It was also associated with higher IgE levels. However, no excess of Arg551 was found in a large cohort of hyper-IgE syndrome patients ${ }^{18}$ and impairment of SHP1 was not replicated $^{19}$. Unlikely in German population lower IgE levels were found in individuals bearing the Arg551 allele ${ }^{20}$. It has 


\section{International Journal of Science and Research (IJSR) ISSN (Online): 2319-7064 \\ Index Copernicus Value (2013): 6.14 | Impact Factor (2014): 5.611}

tight linkage disequilibrium with another variant, Pro478, in IL-4Ra chain of IL-4R. Arg551 also alters STAT6 binding as the phos-phorylation of the substrate STAT6 was reduced in the presence of Pro478 alone. Thus, Pro478 and Arg551 influence signal transduction pathways through IL-4Ra. This could explain the observed association effects with lowered total IgE concentrations. In Japanese populations, in relation to atopic asthma another extracellular variant Ile50Val has been identified ${ }^{21,22}$. Functional assays show that Ile50 up regulates cellular IgE synthesis as well as STAT6 activation. These effects suggest that Ile50 is crucial for enhanced IL-4 and IL-13 signaling. Ile50 is in the extracellular domain of human IL-4Ra next to Cys49; therefore, conformational change or alteration of binding affinity is hypothesized on the basis of a similar extracellular variant, Thr49Ile, in the IL-4Ra chain of BALB/c mice, which might alter the ligandbinding affinity of IL-4Ra ${ }^{23}$. However, computer modeling cannot explain how such a simple amino acid change (Ile/Val 50) acts [27] and the exact mechanism of Ile50 on $\mathrm{IgE}$ up-regulation remains unsolved. Besides Ile50Val, a variant Glu375Ala, is associated with atopy and is in linkage disequilibrium with Cys406Arg in a Japanese population. However, the role of these variants in relation to Ile50 is not yet known.

In contrast with IL-4R, little is known about human IL-13R composed of two components, IL-13Ra1 and IL-13Ra2 chains [1]. Both human IL13RAI and IL13RA2 are single genes on chromosome Xq13. IL-13Ra1 binds weakly to IL13, but a hetero dimer consisting of IL-4Ra and IL-13Ra1 acts as a functional receptor for both human IL-4 and IL-13. IL- 13Ra2 alone binds to its ligand with higher affinity; its functional role, decoy or active, remains unknown. Therefore, IL-13R is called type II IL-4R. But the exact composition of the human IL-4R and IL-13R is not yet known ${ }^{24}$.

Human IL-13R is abundant on non-immune cells, and administration of IL-13 confers an asthma-like phenotype to T-cell- deficient mice ${ }^{4}$, it will be a key area of future study to elucidate whether functional IL-13R is expressed on non immune cells in the lung tissues, and to test if novel variants of the two genes associate with asthma.

\section{IL $4 R \alpha$}

Elevation of IgE levels leads to clinical symptoms of asthma, eczema and rhinitis. It is known that IL-4R $\alpha$ gene shows a strong genetic linkage ${ }^{25}$. A variant of human IL$4 \mathrm{R} \alpha$, which substitute's isoleucine (Ile) for valine (Val), has been identified ${ }^{26}$ and tried to detect whether this variant might promote dys-regulation of $\operatorname{IgE}$ synthesis. They conduct genetic association studies of serum IgE levels in Japanese and British populations ${ }^{22}$ and found a significant difference in Ile/Val50 genotype frequencies between control and atopic subjects in a Japanese population. Ile50 associated with atopic asthma but not non-atopic asthma, also highly significantly associated with raised total serum $\operatorname{IgE}$ levels and mite-specific IgE. Nonetheless, in British population this variant did not show significant association with atopy ${ }^{25}$. Functional effect of Ile50Val on IgE synthesis was also tested by transfected the plasmid encoding human "IL-4Ra carrying either Ile50 or Val50 into a mouse and a human cell line (Fig. 2). It was found that thrice the transcription activity of Ile50-type was enhanced in human IL-4 as compared to Val50-type in both transfect ants. Its mechanism of action has not been described till date ${ }^{22}$.

In Caucasians another variant of IL-4Ra has been discussed, in which glutamine (Gln) at amino acid 551 are replaced with arginine (Arg) in bronchial asthma ${ }^{27,28}$. However this was reported as invariant between control and atopic subjects in both Japanese and British populations ${ }^{29}$. In Germans atopics, its frequency was lower as compared to controls. It was concluded that Arg551Gln does not affect "IL-4 signals ${ }^{2}$.

\section{IL-13R $\alpha 1$}

In German population Izuhara et al in year 2000 identified a novel single nucleotide polymorphism (SNP), A1398G in the non-coding region of the "IL-13R $\alpha 1$ gene based on the cDNA number. This gene was located on the $\mathrm{X}$ chromosome, the incidence of this variant was calculated for atopy in male and female subjects ${ }^{30}$. In the British population, _the incidence was significantly higher in males; however, there was no significant difference in the Japanese population. As this is a silent variant, it would be possible that there is linkage disequilibrium SNP functionally correlated with asthma or alternatively affects expression of IL-13R $\alpha 1^{25}$.

\section{Signal transduction of IL-4 and IL-13}

It had been assumed that IL4 signals through functional IL$4 \mathrm{R}^{31,} 32$ was composed of $\alpha$ chain (IL-4R $\alpha^{\prime}$ ) and the common cytokine receptor $\left(\gamma\right.$ chain $\left(\gamma c^{\prime}\right){ }^{1}$, whereas both IL4 and IL-13 signal through the type II which consists of the IL-4Ra chain and the IL-13Ral chain (Fig. 1). Thereafter in both the mouse and human system in IL 13 two binding units were identified the IL-13R $\alpha$ chain 1 (IL-13R $\alpha 1$ ') and IL-13R $\alpha 2^{4}, 33,34,35$. Additionally in type I IL-4R, hetero dimer consisting of IL-4R $\alpha$ and IL-13R $\alpha$. It is also called type II IL-4R because act as a functional IL-4R ${ }^{33,36}$. Both homo and hetero-dimer (consisting of IL-4R $\alpha$ and either $\gamma \mathrm{c}$ or IL-13R $\alpha 1$ ) of IL-4R $\alpha$ are able to transduce IL-4 signals ${ }^{37}$, 38 . The IL-13 receptor is also composed of the hetero-dimer consisting of IL-13R $\alpha 1$ and IL-4R $\alpha 1$. Both of them are necessary for each other to exert substantial binding activity to IL-13 ${ }^{33}$. It indicates that IL-4 and IL-13 transduce the same signals when they engage type II IL-4R/IL-13R. IL-4 and IL-13 receptors by the ligands induce activation of a variety of signal-transducing molecules ${ }^{1,34}$.

It converges into two pathways: the JAK-signal transducer and activator of transcription (STAT) pathway and the phosphatidyl inositol 3 (PI3)-kinase pathway. JAK - STAT pathway includes JAK1, JAK3 and Tyk 2 activated by Type I receptors whereas JAK1 and Tyk2 activated by Type II receptors, followed by activation of $\mathrm{STAT}^{37,39}$. It plays a central role in the signal transduction of IL-4 and IL-13 including IgE synthesis, Th2 differentiation, proliferation of $B$ cells and T cells and deactivation of monocytes, based on analyses of STAT6-deficient mice and those of the promoter region of the cytokine-targeted genes ${ }^{40,41,42}$. Along with STAT6, IL-4 and IL-13 also activate STAT3, dependent on

\section{Volume 4 Issue 12, December 2015}




\section{International Journal of Science and Research (IJSR) \\ ISSN (Online): 2319-7064 \\ Index Copernicus Value (2013): 6.14 | Impact Factor (2014): 5.611}

expression of "IL-13R $\alpha 1^{43,44}$. It is also thought that though both receptors are engaged by IL-4, type I and type II IL-4R signal pathways are different because they have tyrosine residues located in the $\mathrm{C}$ terminus of IL-13R $\alpha 1$ which are the binding sites for STAT3. It is main point that which type of receptor is expressed to elucidate the signal transduction mechanism of IL- $4^{25}$. Till date, the physiological role of STAT3 on IL-4 and IL-13 signals are unknown. It is of interest to clarify what kinds of genes are induced by STAT3.

Genetic association between a variant of STAT6 and asthma with modest atopy phenotype has been identified in a Japanese population, supporting the candidacy of STAT6 as the ,atopic asthma ${ }^{\text {ee }}$ locus on $12 \mathrm{q}^{45}$. CD23 bind to the D-NA target sequence to which STAT6 binds, therefore, dysfunction of these molecules might promote atopy. A Hind III polymorphism in the first intron of this gene has been identified in relation to marked atopy in a British population $^{46}$, suggesting that BCL6 (act as repressor) might repress STAT6-activated transcription and there by STAT6mediated IL-4 and IL-13 mechanisms. It is anticipated that other molecules might repress STAT6 activity. The identification of novel mechanisms for the STAT6-induced regulation of germ line e transcription may have important implications for future therapeutic development in atopy and asthma ${ }^{47}$. Mutations of JAK3 have been identified in relation to $\mathrm{SCID}^{1}$; however, no common polymorphism has been identified in JAK3. To date, neither a single nucleotide nor microsatellite polymorphism has been identified in either JAK1 or TYK2.

\section{Database included}

The Pub Med based comprehensive literature search was also done. The Medline database was used to gather initial sources for review. The key words used were "Interleukins (IL) 4 and 13" OR "asthma" OR "Cytokines in asthma" and "Interleukins 4 and 13 receptors in asthma". All articles identified by these search terms and related to the study were included for critical review.

\section{Association of IL4 and 13 genes with asthma}

Association of interleukin genes with asthma has been described by various studies (Table 1). Firstly in 1994, Marsh and colleagues ${ }^{7}$ showed a linkage between total serum $\operatorname{IgE}$ and markers on chromosome 5q31-q33, which contains the interleukin-3 (IL-3), IL-4, IL-5, IL-13, and granulocyte-macrophage colony stimulating factor (GMCSF) genes. After that various studies have been performed to assess an association between asthma and Interleukin genes led to inconsistent results with a study. Till now several studies have been conducted in different populations and revealed interesting but conflicting facts about asthma development and interleukin gene variation, with some studies showing positive association with asthma and others showing either protective or no association.

Mitsuyasu and colleagues in year 1998 reported association of Ile50Val polymorphism of IL4R gene polymorphism ${ }^{22}$. Noguchi et al replicate the study in Japanese population in 86 families (375 members including 172 atopic asthma children) and reported Ile50Val polymorphism of IL4R does not play a substantial role in genetic predisposition for the etiology of atopic or asthma ${ }^{48}$.

In Caucasian population, Garcia et al in year 2005 analyzed different polymorphisms of IL4 and ILARA genes particularly, $-33 \mathrm{C}>\mathrm{TIL} 4$ and 576Q $>\mathrm{RIL} 4 R A$ in 212 unrelated individuals, 133 patients with asthma and 79 healthy subjects without symptoms or history of asthma or atopy and with negative skin prick tests. According to multivariate analysis adjusted for age and sex they confirmed that carriers of allele $\mathrm{T}$ had an increased risk of persistent asthma $(\mathrm{OR}=2.77,95 \% \mathrm{CI}=1.18-6.49, \mathrm{P}$ value $=$ $0.019)^{49}$.

In Chinese population, $\mathrm{Li}$ et al in 2009 tried to find out the association of 8 SNPs (IL-13 C1112T, IL-13 C1923T, IL-4 C-590T, IL-4RA I75V, FceR1ß E237G, ß2-ADR Q27E, FceR1ß C-109T and B2-ADR R16G) in 192 asthmatic children and controls. They suggest that FceR1ß C-109T $(\mathrm{OR}=1.96,95 \% \mathrm{CI}=1.31-2.94, \mathrm{P}$ value $=0.001)$ and $32-$ ADR R16G $(\mathrm{OR}=2.58,95 \% \mathrm{CI}=1.66-3.99, \mathrm{P}$ value $=0.000)$ are significantly associated with childhood asthma and have combined effect on the development of asthma ${ }^{50}$. Another study in year 2013 in same population investigated the single and combined associations between the polymorphism (SNP) loci in IL-13 and RANTES genes with the development of asthma and reported the three loci $(I L-13$ C-1112T, IL-13 C1923T, and RANTES A-403G) make little contribution to the development 000000 of asthma in children. IL-13 A2044G and RANTES G-28C are significantly associated with childhood asthma, also have a significant and combined effect on the development of asthma $(\mathrm{OR}=2.59, \quad P=0.0001 ; \mathrm{OR}=3.00, \quad, \quad P$ $=0.0001$ :respectively $)^{51}$.

In Asian population Weidong et al in year 2007 determined Ile50Val and Q576R polymorphisms of IL4R gene in Chinese, Malay and Indian populations. They observed that heterozygote of Ile $50 \mathrm{Val}$ is less frequent in asthmatics than in controls in Malay population and no difference was found in Chinese and Indian population. Ile50/Ile50 was more prevalent in higher total serum IgE group in Malay. The prevalence of Ile50/R576 haplotype was lower in asthmatics than controls in Chinese while the prevalence of Ile50/Q576 haplotype was lower in asthmatics than in controls in Malay $^{52}$. Cohort study in year 2003, has been done in 368 children and 548 parents of those children to investigate the haplotype association of IL13 Arg130Gln and C1112 T polymorphisms. The suggest that the IL13 Arg130Gln polymorphism and haplotype consisting of IL13 Arg130GIn and IL4 C589 T were associated with the development of atopy and atopic dermatitis at 24 months of age $\mathrm{s}^{53}$.

In Pakistani population a study has been performed by Micheal in year 2013, with 108 asthmatics and 106 allergic rhinitis patients along with 120 healthy controls. All were genotyped for IL-4 SNPs, C-589T (rs2243250), T+2979G (rs2227284), and C-33T (rs2070874). They indicated significant association of SNP rs2243250 both with asthma $(P=.004, \mathrm{OR}=11.0)$ and allergic rhinitis $(P<.001, \mathrm{OR}=20.2)$, as was T-2979G $(P<.001, \mathrm{OR}=22.51$ for asthma and $P<.001$, $\mathrm{OR}=57.6$ for allergic rhinitis). The most frequent genotypes

\section{Volume 4 Issue 12, December 2015}




\section{International Journal of Science and Research (IJSR) \\ ISSN (Online): 2319-7064}

Index Copernicus Value (2013): 6.14 | Impact Factor (2014): 5.611

in the asthma and allergic rhinitis groups were TT for SNP rs2243250 and GG for SNP rs2227284.in Pakistani cohort ${ }^{54}$.

In Indian context some studies have reported association of interleukins with asthma. Such as Nagarkatti et al in year 2004, performed a case-control study and reported that promoter region of the ILA gene is invariant in north India but a significant difference was observed in CA repeat polymorphisms in the second intron of IL- $4^{55}$. Moreover these findings was supported by Mahdi et al in year 2010, they also revealed no association of IL4 and ADAM33 gene SNPs with asthma in Indian population ${ }^{56}$.

Another study in year 2013 from south India reported positive association of IL 4 C590T and elevated levels of serum IgE. They enrolled 56 atopic asthma patients and 42 healthy control subject equivalent gender, age, and ethnicity. Their results have shown that $I L-4-590 \mathrm{~T}$ allele may be a risk factor for the development of asthma and atopy in the south Indian population $(\mathrm{OR}=0.302,95 \% \mathrm{CI}=0.2856-0.319, \mathrm{P}$ value $=0.044)$. Patients who carried T allele of $-590 \mathrm{C} / \mathrm{T} I L-4$ also showed an increased risk of allergic asthma ${ }^{57}$.

Dixit et al in 2014 reported significant association of IL 4R and IL 13 in Indian asthmatic children. They enrolled 275 cases and 275 controls $^{58}$.

Gene- gene interaction has also been identified in Dutch population in year 2001, suggested that variations in IL4RA contribute to elevated total serum IgE levels, and interaction between ILARA and IL13 markedly increases an individual's susceptibility to asthma. A significant gene-gene interaction between S478P in ILARA and promoter variation in IL13, found to be associated with BHR individuals ${ }^{59}$. Another study in year 2006, investigated the relationship of IL-13 and IL-13Ra1 polymorphisms with IgE production in Korean children with asthma. They enrolled 358 atopic asthmatic, 111 non-atopic asthmatic, and 146 non-atopic healthy children and reported that gene- gene interaction between risk alleles of each IL-13 promoter polymorphism and IL-13Ra1 polymorphism was associated with higher total $\operatorname{IgE}$ in children with atopic asthma $(\mathrm{P}=0.002,0.010)^{60}$. Later on by Natalie et al in year 2007, significant gene-gene interaction was found between the IL-13 (A646G) and IL4R (A4679G) SNPs for baseline lung function in Africans and Americans ${ }^{61}$.

\section{Conclusion}

Genetic and functional analyses provide increasing evidence that there are major loci for asthma in relation to signaling of IL-4 and IL-13 through IL-4Ra- STAT6. They are essential for the action of both cytokines, and for the development of the disease asthma.

Till date, however, no common variant of the genes in this pathway is associated across the different ethnic groups with phenotypes. Moreover the interaction of variants, which might be in linkage disequilibrium to each other, can potentiate rather than add to functional effects. It shows that the genetic etiology of asthma is far more complex than we expected, in relation to molecular heterogeneity and genetic interaction within and among molecules on IL-4/IL-13 signaling.

Future statistical genetic analysis might allow prediction of asthma phenotypes among different ethnic groups, as well as potential interactions between different variants. Studies on IL-4/IL-13 signaling highlighted the etiological relationship of asthma. Epidemiological data suggest that atopy is the strongest risk factor for the development of asthma, but in some cases asthma may be independent phenomena. This hypothesis is concordant with animal models where mechanisms responsible for asthma are independent of $\operatorname{IgE}$ levels. Functional alteration of the ligands or the receptors in IL-4/IL-13 signaling might act on B cells producing IgE antibody, while allowing naive $\mathrm{T}$ cells to differentiate towards Th2 cells; these may occur in the same time course. This might explain why the majority of asthmatics are also atopic. Comparison of functional genotype among key genes between atopic and non atopic can clarify this point. Therefore further studies with appropriate sample size in different populations with asthma with well defined criteria will help to characterize a possible role of interleukin genes in a etiology of asthma disease.

\section{References}

[1] Izuhara K and Shirakawa T. Signal transduction via the interleukin-4 receptor and its correlation with atopy. Int J Mol Med 1999; 3: 3-10.

[2] Humbert M, Durham SR, Kimmitt P, Powell N, Assoufi $\mathrm{B}$, Pister $\mathrm{R}$ et al. Elevated expression of messenger ribonucleic acid en' coding IL-13 in the bronchial mucosa of atopic and non-atopic subjects with asthma. J Allergy Clin Immunol 1997;99: 657-665.

[3] Naseer T, Minshall EM, Leung DY, Laberge S, Ernst P, Martin RJ et al. Expression of IL-12 and IL-13 mRNA in asthma and their modulation in response to steroid therapy. Am J Respir Crit Care Med 1997;155: 845851.

[4] Grünig G, Warnock, Wakil AE, Venkayya R, Brombacher F, Rennick DM et al. Requirement for IL13 independently of IL-4 in experimental $\mathrm{K}$ asthma. Science 1998; 282:2261-2263.

[5] Wills-Karp M, Luyimbazi J, Xu X, Schofield B, Neben TY, Karp CL et al. Interleukin-13: central mediator of allergic asthma. Science 1998; 282:2258-2261.

[6] Zhu Z, Homer RJ, Wang Z, Chen Q, Geba GP, Wang et al. Pulmonary expression of interleukin-13 causes inflammation, mucus hyper-secretion, sub-epithelial fibrosis, physiologic abnormalities, and eotaxin production. J Clin Invest 1999; 103: 779-788.

[7] Marsh DG, Neely JD, Breazeale DR, Ghosh B, Freidhoff LR, Ehrlich-Kautzky E et al. Linkage analysis of IL-4 and other chromosome 5q31.1 markers and total serum immunoglobulin $\mathrm{E}$ concentrations. Science 1994;264: 1152-1156.

[8] The collaborative study on the genetics of asthma. A genome-wide search for asthma susceptibility loci in ethnically diverse populations. Nat Genet 1997 ;15: 389-392.

[9] Ober C Cox NJ, Abney M, Di Rienzo A, Lander ES, Changyaleket B et al. Genome-wide search for asthma 


\section{International Journal of Science and Research (IJSR) ISSN (Online): 2319-7064 \\ Index Copernicus Value (2013): 6.14 | Impact Factor (2014): 5.611}

susceptibility loci in a founder population. Hum. Mol. Genet. 1998;9: 1393-1398.

[10] Deichmann KA, Heinzmann A, Forster J, Dischinger S, Mehl C, Brueggenolte $\mathrm{E}$ et al. Linkage and allelic association of atopy and markers flanking the IL-4receptor gene. Clin Exp Allergy 1997; 28:151-155.

[11] Noguchi E, Shibasaki M, Arinami T, Takeda K, Maki $\mathrm{T}$ et al. Evidence for linkage between asthma/atopy in childhood and chromosome 5q31-q33 in a Japanese population. Am J Respir Crit Care Med 1997; 156: 1390-1393.

[12] Hook S, Cheng P, Holloway J, Riley G, Sawyer G, Le Gros G, Beasley R et al. Analysis of two IL-4 promoter polymorphisms in a cohort of atopic and asthmatic subjects. Exp Clin Immunogenet 1999; 16: 33-35.

[13] Parry RG, Gillespie KM, Parnham A, Clark AG, Mathieson PW. Interleukin-4 and interleukin-4 receptor polymorphisms in minimal change nephropathy. Clin Sci 1999; 96,665-668.

[14] Rosenwasser LJ and Borish L. Genetics of atopy and asthma: the rationale behind promoter-based candidate gene studies (IL-4 and IL-10). Am J Respir Crit Care Med 1997; 156: S152-S155.

[15] Van der Pouw Kraan TCTM, Veen AV, Boeije L C M, Van Tuyl SAP, Groot E R, Stapel S O et al. An IL-13 promoter polymorphism associated with increased risk of allergic asthma. Genes Immunity 1999; 1: 61-65.

[16] Hershey GK, Friedrich MF, Ebsswein LA, Thomas ML and Chatila TA. The association of atopy with a gainof-function mutation in the subunit of the interleukin-4 receptor. N Engl J Med 1997; 337: 1720-1725.

[17] Glimbacher B, Schäffer AA, Holland SM, Davis J, Gallin JI, Malech HL, et al. The interleukin-4 receptor variant Q576R in hyper-IgE syndrome. New Engl J Med 1998; 338:1073-1074.

[18] Wang HY, Shelburne CP, Zamorano J, Kelly AE, Ryan JJ, Keegan AD. Effects of an allergy associated mutation in the human IL-4Ra (Q576R) on human IL-4induced signal transduction. J Immunol 1999; 162:4385-4389.

[19] Kruse S, Japha T, Tedner M, Sparholt SH, Forster J, Kuehr J et al. The polymorphisms S503P and Q576R in the interleukin-4 receptor gene are associated with atopy and influence the signal transduction. Immunology 1999; 96: 365-371

[20] Mitsuyasu H, Yanagihara Y, Mao XQ, Gao PS, Arinobu $\mathrm{Y}$, Ihara $\mathrm{K}$ et al. Dominant effect of Ile50Val variant of the human IL-4 receptor a-chain in IgE synthesis. J Immunol 1999; 162: 1227-1231.

[21] Mitsuyasu H, Izuhara K, Mao XQ, Gao PS, Arinobu Y, Enomoto $\mathrm{T}$ et al. Ile50Val variant of IL-4Ra upregulates IgE synthesis and associates with atopic asthma. Nat. Genet. 1998; 19: 119-120.

[22] Schulte T, Kurrle R, Rollinghoff M, Gessner A. Molecular characterization and functional analysis of murine interleukin 4 receptor allotypes. J Exp Med 1997; 186:1419-1429.

[23] Donaldson DD, Whitters MJ, Fitz LJ, Neben TY, Finnerty H, Henderson HL et al. The murine IL-13 receptor a2: molecular cloning, characterization, and comparison with murine IL-13 receptor a1. J Immunol 1998; 161: 2317-2324.
[24]Izuhara K, Suyama UR, Akaiwa M, Shirakawa T, Deichmann K, Arima $\mathrm{K}$ et al. Recent Advances in Understanding How Interleukin 13 Signals Are Involved in the Pathogenesis of Bronchial Asthma. Archivum Immunologiae et Therapiae Experimentalis 2000; 48: 505-512.

[25] Chiaramonte MG, Schopf LR, Neben TY, Cheever AW, Donaldson DD, Wyynn TA. IL-13 is a key regulatory cytokine for Th2 cell-mediated pulmonary granuloma formation and $\mathrm{IgE}$ responses induced by Schistosoma mansoni eggs. J Immunol 1999; 162:920-930.

[26] Khurana Hershey GK, Friedrich MF, Esswein LA, Thomas ML and Chatila TA. The association of atopy with a gain-of-function mutation in the subunit of the interleukin-4 receptor. N Engl J Med 1997:337, 1720 1725.

[27] Rosa-Rosa L, Zimmermann N, Bernstein JA, Rothenberg ME and Khurana Hershey YGK. The R576 IL-4 receptor allele correlates with asthma severity. J. Allergy Clin Immunol 1999; 104:1008-1014.

[28] Takabayashi A, Ihara K, Sasaki Y, Izuhara K, Hamasaki N, Suzuki Y et al. Association between childhood atopic asthma and polymorphisms of three candidate genes: interleukin-4 receptor, interleukin-4 promoter and Fc receptor genes. Exp Clin Immunogenet 2000; 17:63-70.

[29] Heinzmann A, Mao XQ, Akaiwa M, Kreomer RT, Gao PS, Ohshima $\mathrm{K}$ et al. Genetic variants of IL-13 signaling and human asthma and atopy. Hum Mol Genet 2000; 9: 549-559.

[30] Fujiwara H, Hanissian SH, Tsytsykova A, Geha RS. Homo- dimerization of the human interleukin 4 receptor chain induces germline transcripts in b cells in the abdsence of the interleukin 2 receptor chain. Proc Natl Acad Esci 1997; 94: 5866-5871.

[31] Reichel M, Nelson BH, Greenberg PD, Rothman PB. The il-4 receptor-chain cytoplasmic domain is sufficient for activation of JAK-1 and STAT6 and the induction of il-4-specific gene expression. J Immunol 1997; 158, 5860-5867.

[32] Aman MJ, Tayebi N, Obiri NI, Puri RK, Modi WSK and Leonard WJ. cdna cloning and characterization of the human interleukin 13 receptor chain. J Biol Chem 1996;271, 29265-29270.

[33] Caput D, Laurent P, Kaghad M, Lelias JM, Lefort S, Vita N, Ferrara P. Cloning and characterization of a specific interleukin (IL)-13 binding protein structurally related to the il-5 receptor chain. J Biol Chem 1996; 271:16921-16926.

[34]Donaldson DD, Whitters MJ, Fitz IJ, Neben TY, Finnerty H, Henderson SL et al. The murine IL-13 receptor 2: molecular cloning, characterization, $\mathrm{K}$ and comparison with murine il-13 receptor. J Immunol 1998; 161, 2317-2324.36.

[35] Murata T, Taguchi J and Puri RK. Interleukin-13 receptor but not chain: a functional component of interleukin-4 receptors. Blood 1998; 91:3884-3891.

[36] Izuhara K, Heike T, Otusuka T, Yamaoka K, Mayumi $\mathrm{M}$, Imamura $\mathrm{T}$ et al. Signal transduction pathway of interleukin-4 and interleukin-13 in human B cells derived from $\mathrm{X}$-linked severe combined immunodeficiency patients. J Biol Chem 1996; 271,619-622. 


\section{International Journal of Science and Research (IJSR) \\ ISSN (Online): 2319-7064 \\ Index Copernicus Value (2013): 6.14 | Impact Factor (2014): 5.611}

[37] Moriggl R, Erhardt I, Kammer W and Berchtold S. Activation of STAT6 is not dependent on phosphotyrosine- mediated docking to the interleukin-4 receptor and can be blocked by dominant-negative mutants of both receptor subunits. Eur J Biochem 1998; 251: $25-35$.

[38] Nelms K, Keegan AD, Zamorano J, Ryan JJ and Paul ZWE. The il-4 receptor: signaling mechanisms and biologic functions. Annu Rev Immunol 1999; 17:701738.

[39] Kaplan MH, Schindler U, Smiley ST. and Grusby MJ. STAT6 is required for mediating responses to IL-4 and for development of Th2 cells. Immunity 1996; 4: 313319.

[40] Mikita T, Campbell D, Wu P, Williamson K and Schindler U. Requirements for interleukin-4-induced gene expression and functional characterization of stat6. Mol Cell Biol 1996; 16:5811-5820.

[41] Shimoda K, Van Deursen J, Sangster MY, Sarawar R, Carson RT, Tripp RA et al. Lack of IL-4-induced Th2 response and $\mathrm{IgE}$ class switching in mice with disrupted STAT6 gene. Nature 1996; 380:630-633.

[42] Umeshita SR, Sugimoto R, Akaiwa M, Arima K, Yu B, Wada $M$ et al. Characterization of IL-4 and IL-13 signals dependent on the human IL-13 receptor chain: redundancy of requirement of tyrosine residue for STAT3 activation. Int Immunol 2000; 12, 1499-1509.

[43] Orchansky PL, Kwan R, Lee F. and Schrader JW. Characterization of the cytoplasmic domain of interleukin-13 receptor. J Biol Chem 1999; 274: 20818 20825.

[44] Gao PS, Mao XQ, Roberts M, Arinobu Y, Akaiwa M, Enomoto T et al. Variants of STAT6 in atopic asthma. J Med Genet 2000; 37:380-382.

[45] Adra, c.n. Gao PS, Mao XQ, Baron BW, Pauker S, Miki $\mathrm{T}$, et al. Variants of $\mathrm{b}$ cell lymphoma 6 (Bcl6) and marked atopy. Clin Genet 1998; 54: 362-364.

[46] Kamogawa, Y, Lee HJ, Johnston JA, McMahon M, O' Garra A, Arai $\mathrm{N}$ et al. A conditionally active form of STAT6 can mimic certain effects of IL-4. J Immunol 1998; 161: 1074-1077.

[47] Noguchi E, Shibasaki M, Arinami T, Takeda K, Yokouchi Y, Kobayashi K et al. No association between atopy/asthma and the ile50val polymorphism of il-4 receptor. Am J Respir Crit Care Med 1999; 160:342345.

[48] García IM, Dávila I, Laffond E, Moreno E, Lorente F and Sarmiento GR. Interleukin-4 (IL4) and interleukin4 receptor (IL4ra) polymorphisms in asthma: a case control study. Clinical and molecular allergy 2005, $3: 15$.
[49] Li H, Xiaoyan D, Quanhua L, Jie L, Yixiao B. Singlenucleotide polymorphisms in genes predisposing to asthma in children of Chinese Han nationality. J Investig Allergol Clin Immunol 2009; 19: 391-395.

[50] Quanhua L, Li H, Dingzhu F, Qian L, Yaju Z, Xinxin Gan et al. Interleukin-13 and rantes polymorphisms in relation to asthma in children of chinese han nationality. Asian Pac J Allergy Immunol 2013; 31:247-52.

[51] Zhang W, Zhang X, Qiu D, Sandford A, Wan C, Tan CW. Il-4 receptor genetic polymorphisms and asthma in Asian populations. Respiratory Medicine 2007;101:186-190.

[52] He JQ, Yeung MC, Becker AB, Ward DH, Ferguson AC, Manfreda J et al. Genetic variants of the il13 and il4 genes and atopic diseases in at-risk children. Genes and immunity 2003; 4:385-389.

[53] Micheal S, Minhas K, Ishaque M, Ahmed F, Ahmed A. Il-4 gene polymorphisms and their association with atopic asthma and allergic rhinitis in pakistani patients. J Investig Allergol Clin Immunol 2013; 23: 107-111.

[54] Nagarkatti R, Kumar R, Sharma KS, Ghosh B. Association of IL 4 gene polymorphisms with asthma in north Indians. Int Arch Allergy Immunol 2004; 134:206-212.

[55]Bijanzadeh M, Ramachandra BN, Mahesh PA, Mysore SR, Kumar P, Manjunath BS et al. Association of il-4 and adam33 gene polymorphisms with asthma in an Indian population. Lung 2010;188:415-422.

[56] Vishnumaya CP, Sudha S, Suhail N, Gemitha G, Saranya RS, Sreejaya. Association of -590C/T Interleukin-4 gene promoter polymorphism with atopic asthma in south Indian people. International Journal of Bioassays 2013; 02:723-726.

[57]Dixit P, Awasthi S, Agarwal S. Association of Interleukin genes polymorphism with asthma susceptibility in Indian Children: A case- control study. Annals of Human Biology; 2014:1-8.

[58] Howard DT, Koppelman GH, Xu J, Zheng SL, Postma $\mathrm{SD}$, Meyers DA et al. Gene-gene interaction in asthma: IL 4ra and IL 13 in a Dutch population with asthma. Am J Hum Genet 2002; 70:230-236.

[59] Kim BH, Lee CY, Lee SW, Jung J, Jin SH, Kim JH et al. Gene-gene interaction between IL-13 and IL-13Ra1 is associated with total $\operatorname{IgE}$ in Korean children with atopic asthma. J Hum Genet 2006; 51:1055-1062.

[60]Battle CN, Choudhry S, Tsai JH, Eng C, Kumar G, Beckman $\mathrm{K}$ et al. Ethnicity-specific Gene-Gene Interaction between IL-13 and IL-4R among African Americans with Asthma.. Am J Respir Crit Care Med 2007; 175: 881-887. 
International Journal of Science and Research (IJSR)
ISSN (Online): 2319-7064

Index Copernicus Value (2013): 6.14 | Impact Factor (2014): 5.611

Table 1: Interleukin 4 \&13 genes and receptor polymorphisms studied in different populations in relation to asthma

\begin{tabular}{|c|c|c|c|c|c|c|}
\hline S. no & $\begin{array}{c}\text { Polymorphisms } \\
\text { studied }\end{array}$ & Population & Study Design & Cases/sample size & Association & Authors \\
\hline 1 & IL 4R (Ile50Val) & Japanese & Case-control & $\begin{array}{l}\text { Asthmatics- } 172 \\
\text { Controls - } 15\end{array}$ & Negative & Nogouchi et al; 1999 \\
\hline 2 & $\begin{array}{l}\text { IL4 receptor } \\
\text { (IL4RA) }\end{array}$ & $\begin{array}{l}\text { African Americans, } \\
\text { European Americans } \\
\text { and East Asians } \\
\end{array}$ & Cohort Study & Healthy Individuals- 12 & Positive & $\begin{array}{l}\text { Wu et al; } \\
2001\end{array}$ \\
\hline 3 & $2^{\text {nd }}$ Intron of IL 4 & North Indian & Case-control & $\begin{array}{l}\text { Asthmatic probands- } \\
171 \text { Controls- } 128\end{array}$ & Negative & Nagarkatti et al; 2003 \\
\hline 4 & $\begin{array}{l}-33 \mathrm{C}>\mathrm{TIL} 4 \text { and } \\
576 \mathrm{Q}>\mathrm{RILARA}\end{array}$ & Caucasian & Case-control & $\begin{array}{l}\text { Asthma- } 133 \text { Healthy } \\
\text { subjects- } 79\end{array}$ & Negative & Maria et al; 2005 \\
\hline 5 & $\begin{array}{l}18 \text { SNPs in IL-4, } \\
\text { IL-13, and IL- } \\
4 \mathrm{R} \text { genes }\end{array}$ & African- American & Cohort Study & Asthmatics- 24 & Negative & Natalie et al; 2006 \\
\hline 6 & IL 4R (Ile50Val) & $\begin{array}{l}\text { Asian } \\
\text { population(Chinese, } \\
\text { Malaysian and Indian) }\end{array}$ & Case-control & $\begin{array}{l}\text { Asthmatics-303 } \\
\text { Controls-355 }\end{array}$ & Negative & Weidong et al; 2007 \\
\hline 7 & $\begin{array}{l}\text { IL } 4 \text { (C590T) } \\
\text { IL } 13(\mathrm{C} 1112 \mathrm{~T})\end{array}$ & Chinese & Case-control & $\begin{array}{l}\text { Asthma-192 } \\
\text { Controls-192 } \\
\end{array}$ & Negative & Li et al; 2009 \\
\hline 8 & IL 4 (C590T) & Indian & Case-control & $\begin{array}{l}\text { Asthmatics-200 } \\
\text { Controls-100 }\end{array}$ & Negative & $\begin{array}{l}\text { Mahdi et al; } \\
2010\end{array}$ \\
\hline 9 & $\begin{array}{l}\text { IL 4R } \\
\text { (Glu375Arg) } \\
\text { IL13 (C-111T) }\end{array}$ & American & Case-control & $\begin{array}{l}\text { Asthmatic pro-band- } \\
407 \\
\text { Asthmatic cases- } 118 \\
\text { Allergic rhinitis- } 188 \\
\text { Unrelated controls }\end{array}$ & Positive & $\begin{array}{l}\text { Renske etal; } \\
2010\end{array}$ \\
\hline 10 & IL 13 (C112T) & Chinese & Case-control & $\begin{array}{l}\text { Asthmatics- } 384 \\
\text { Controls- } 384\end{array}$ & Negative & Quanhua et al; 2012 \\
\hline 11 & IL 4 (C590T) & Pakistanis & Case-control & $\begin{array}{l}\text { Asthma-108 } \\
\text { Allergic rhinitis-106 } \\
\text { Healthy Controls } 120 \\
\end{array}$ & Positive & Micheal et al; 2013 \\
\hline 12 & IL 4 (C590T) & South Indian & Case-control & $\begin{array}{l}\text { Atopic asthma- } 56 \\
\text { Healthy control- } 42\end{array}$ & Positive & $\begin{array}{l}\text { Vishnumaya et al; } \\
2013\end{array}$ \\
\hline 13 & $\begin{array}{l}\text { IL } 4 \text { (C590T) } \\
\text { IL 4R (Ile50Val) } \\
\text { IL 13 (C1112T) } \\
\text { IL 13 R } \\
\text { (A1398G) }\end{array}$ & Indian & Case-control & $\begin{array}{l}\text { Asthmatics- } 275 \\
\text { Controls- } 275\end{array}$ & Positive & Dixit et al 2014 \\
\hline
\end{tabular}

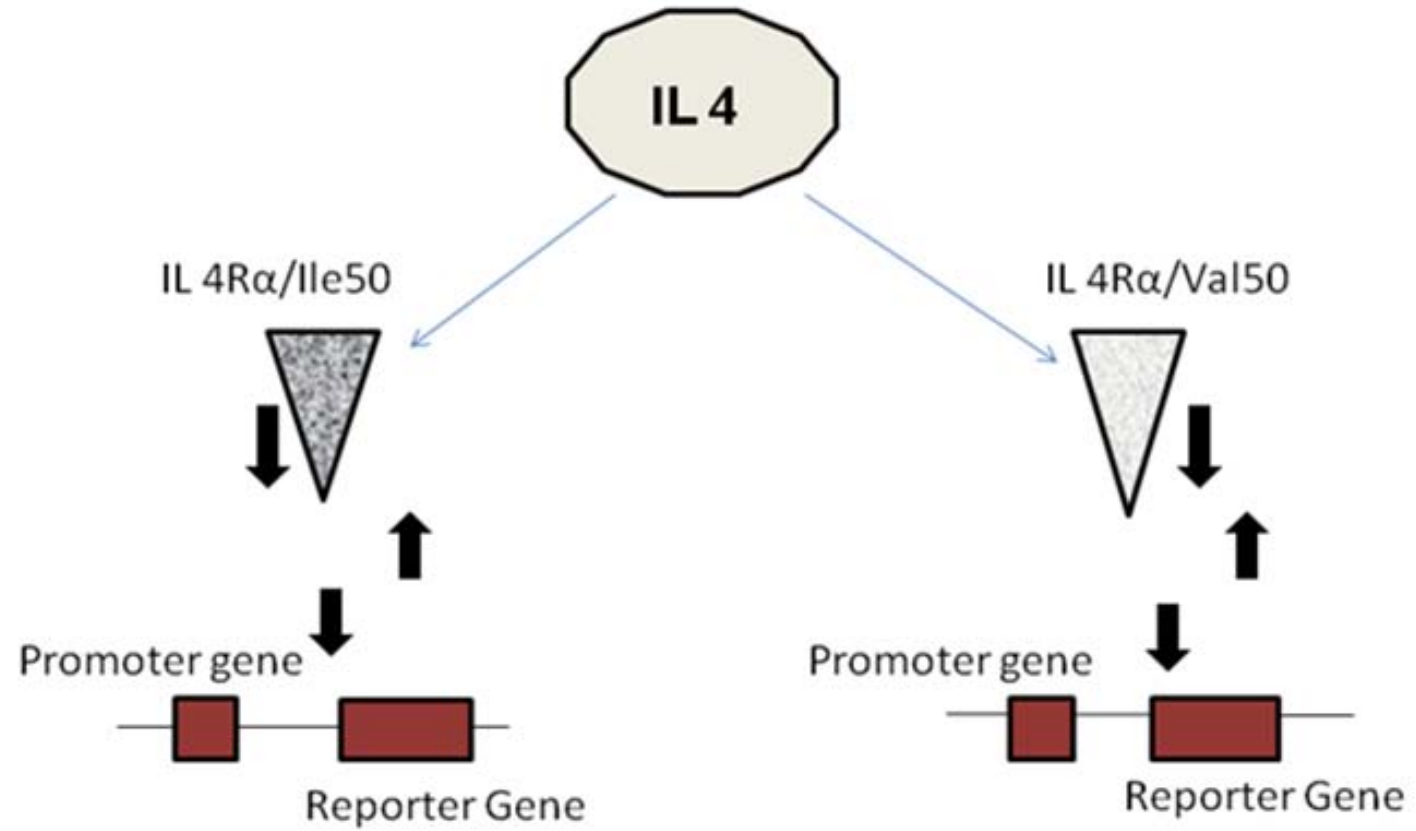

Fig. 1. Effects of Ile50Val on $\mathrm{IL} 4$ signals. A schematic model of Ile50Val effects on $\mathrm{IL} 4$ signals is depicted. Upon stimulation of $\mathrm{IL} 4$, Ile50-typed IL $4 R u$ tranducers stronger signals than Val50 -typed IL $4 R u$.

\section{Volume 4 Issue 12, December 2015}


International Journal of Science and Research (IJSR)

ISSN (Online): 2319-7064

Index Copernicus Value (2013): 6.14 | Impact Factor (2014): 5.611

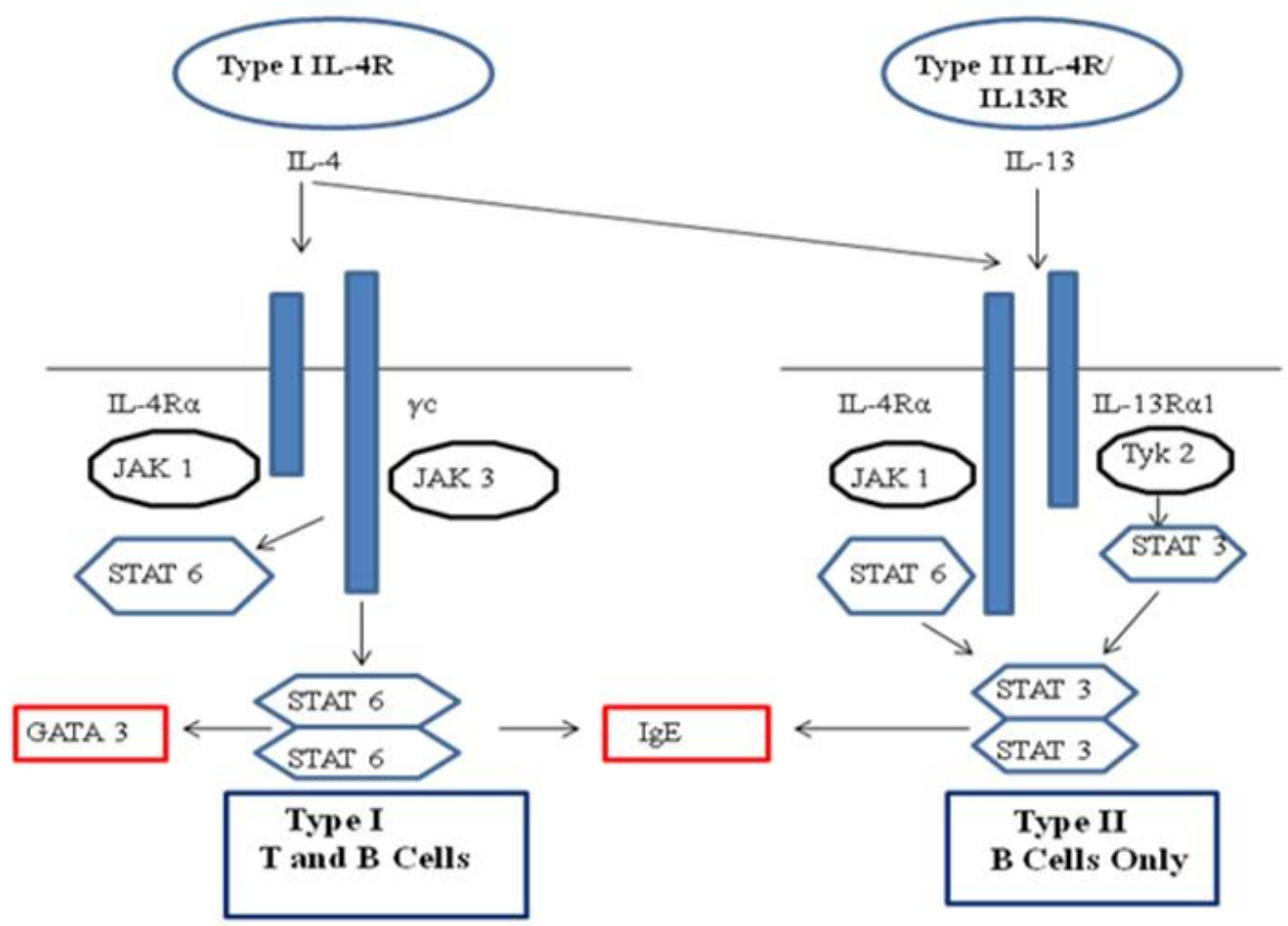

Fig 2. Signal transduction pathways of IL-4 and IL-13. A schematic model of signal transduction pathways of IL 4 and 13 is depicted. Note that type II IL-4R/IL-13R tranduces the STAT3 pathway in addition to the STAT6 pathway. 